\title{
Insight/Outlook
}

\section{Gaucher Disease Phenotypes Outflanked?}

\author{
Ernest Beutler ${ }^{1}$
}

\author{
Department of Molecular and Experimental Medicine, The Scripps Research Institute, La Jolla, California 92037 USA
}

ne of the major puzzles in modern human genetics is the fact that patients with the same genotype for a diseasecausing mutation may express very different clinical manifestations. Gaucher disease is one of the more common, clinically important, autosomal recessive disorders. In this issue, Winfield et al. (1997) point out that the problem of phenotypic variation is a serious one in this disorder and that understanding the cause of this variation is of great practical importance. Our ability to provide useful prenatal counseling is hampered by the variability of outcome, even when the gen otype of the fetus has been established.

The identification of three new genes close to the gl ucocerebrosidase (GBA) locus enriches our understanding of this important area of chromosome 1. But whether the presence of important genes adjacent to the GBA locus can explain the variability of the manifestations of Gaucher disease raises two distinct questions: The first concerns the cause of the variation that exists between individuals with the same genotype; and the second relates to the cause of the variation between patients who have different Gaucher disease genotypes. The first of these questionspatients with the same genotype-is the most vexing, because the difference be tween clinical expression of patients with different genotypes seems related, at least in part, to the severity of the glucocerebrosidase deficiency produced.

To explain the differences between individuals who have the same GBA genotype we must consider the fact that such differences can occur within the context of three different circumstances: (1) in identical twins, in which case the cause of variability is most probably environmental; (2) in sibs, in which case the cause of variability can be environmental or genetic, but if genetic, is un-

${ }^{1}$ E-MAIL beutler@scripps.edu; FAX (619) 7842083. likely to be tightly linked to the GBA locus; and (3) between apparently unrelated members of the general population, in which case variation in genes linked to the GBA locus might be the cause. However, in the case of the common Gaucher disease mutations it is now clear that virtually all individuals with a given common mutation have inherited all of the same genes in the re gions flanking the GBA locus. Another map of this region (Demina et al. 1997) indicates that the distance between the 5 ' ends of red cell/liver pyruvate kinase gene (PKLR) is $71 \mathrm{~kb}$, well beyond the downstream loci identified by Winfield et al. (this issue). Polymorphic sites exist within the PKLR locus; a study of 195 Gaucher disease patients with the 1226G/1226G genotype, representing 390 chromosomes, showed that all had a - / - haplotype both in the GBA and the PKLR gene at nucleotide 1705. All 56 Gaucher disease patients who were 1226G/84GG compound heterozygotes manifested a - /+GBA haplotype and 55 of these were $-/+$ at PKLR nucleotide 1705 (Glenn et al. 1994; Demina et al. 1997). These findings are supported by those of Cormand et al. (1997), who show a lack of crossovers at an even longer distance, extending over $3.2 \mathrm{cM}$. Although the common $1448 \mathrm{C}$ mutation occurs in the context of more than one haplotype, the $1448 \mathrm{C}$ mutation that occurs in Norbottnia is certainly of a single origin, and here, too, marked phenotypic variation occurs (Erikson 1986). Thus, the common Gaucher disease mutations are of recent origin, arising from common founders, and because of this virtually all patients are like brothers and sisters in that the flanking regions they have inherited are exactly the same. Accordingly, the variability in the phenotype of Gaucher disease patients is unlikely to be explained by mutations in the genes in the flanking regions. The possibility that a new mutation has arisen in one of these genes in the flanking region cannot be totally dismisssed, but is unlikely considering that the 1226 $\mathrm{G}$ mutation for example, is probably only between 500 and 2000 years old (Beutler 1997). Is there any other way in which these genes could explain variability in the Gaucher disease phenotype? Only if variation in expression of these genes resulted from environmental factors or unlinked regulatory genes. One cannot rule out such a possibility, but the same types of factors could be altering the expression of the GBA gene itself, so it does not seem necessary to involve genes in the flanking regions.

A more plausible case may be made to explain the phenotypes caused by different GBA mutations on the basis of mutations occurring in the tightly linked flanking genes. One need not invoke such an explanation for most Gaucher disease mutations because the reason that some mutations are mild and some severe is often obvious. The $84 \mathrm{GG}$ mutation, which has very severe phenotypic consequences and appears, on the basis of population data, to be lethal in the homozygous state, causes a frameshift in the leader sequence and prevents the formation of any enzyme. The 1448C mutation, which is associated with severe disease, results in a substitution of a helix-terminating proline for a leucine (L444P), but the 1226G (N370S) mutation results in the formation of fairly abundant, although kinetically abnormal, enzyme (van Weely et al. 1993) and would, therefore, be expected to have a milder effect. A further finding, compatible with the explanation that variation in phenotype is the result of the mutations in the GBA gene itself, comes from the fact that there is usually less residual activity in the leukocytes of patients with type 2 and type 3 disease than in type 1 disease (Beutler et al. 1984; Meivar-Levy et al. 1994). However, there is at least one clinical syndrome that is difficult to explain on the basis of decrease in glucocerebrosidase activity alone, and Mistry (1995) has already proposed that this mutation may 
be closely linked to another genetic lesion or that it may alter the transcript of a convergently transcribed gene. The mutation in question is 1342C (D409H), that in the homozygous state seems invariably to be associated with calcifications of cardiac valves and corneal opacities (Uyama et al. 1992, 1997; Abrahamov et al. 1995; Beutler et al. 1995; Chabas et al. 1995) as well as the classical manifestations of Gaucher disease. This phenotype is sufficiently unique that it was accorded a designation in the Online Mendelian Inheritance in Man (OMIM) catalog separate from Gaucher disease (231005 Gaucherlike disease. Pseudo-Gaucher disease). The $1342 \mathrm{C}$ mutation is not altogether rare (Horowitz et al. 1993; Cormand et al. 1995; Michelakakis et al. 1995; Hrebicek et al. 1996; Ida et al. 1997; Le Coutre et al. 1997). Consistent with a common origin is the fact that seven of the eight examples we have encountered are in the context of the -Pvu haplotype and the other is indeterminate. That this mutation confers a gain of function seems unlikely both because of the recessive nature of the phenotype and because the mRNA with this mutation has been found to be unstable (Pasmanik-Chor et al. 1997). Perhaps a tightly linked mutation in one of the nearby genes that are described by Winfield et al. (this issue) causes the unusual manifestations found in 1342C homozygotes.

Although it seems that the extent to which variability specifically in Gaucher disease phenotypes may be explained by genes in flanking regions could be very limited, we know little, in general, of the roles that adjacent genes may have in influencing expression. Good maps of important regions are necessary to begin such studies. For example, interference may occur when transcription of two adjacent genes is convergent, either at the transcriptional level, itself, or through the formation of antisense transcripts. Other mechanisms will surely be found. The last decade has taught us that there are genetic mechanisms that no one dreamed of.

\section{REFERENCES}

Abrahamov, A., D. Elstein, V. Gross-Tsur, B. Farber, Y. Glaser, I. Hada-Halpern, S. Ronen, M. Tafakjdi, M. Horowitz, A. Zimran, and I. Hadas-Hal pern 1995. Lancet 346: 1000-1003.
Beutler, E. 1997. In Advances in Jewish Genetic Diseases (ed. R.J. Desnick), Oxford University Press, New York, NY. (In press).

Beutler, E., W. Kuhl, and J. Sorge. 1984. Proc. Natl. Acad. Sci. 81: 6506-6510.

Beutler, E., C. Kattamis, J. Sipe, and M. Lipson. 1995. Lancet 346: 1637.

Chabas, A., B. Cormand, D. Grinberg, J.M. Burguera, S. Balcells, J.L. Merino, I. Mate, J.A. Sobrino, R. Gonzalez-Duarte, and L. Vilageliu. 1995. J. Med. Genet. 32: 740-742.

Cormand, B., L. Vilageliu, J.M. Burguera, S. Balcells, R. Gonzalez-Duarte, D. Grinberg, and A. Chabas. 1995. Hum. Mutat. 5: 303309.

Cormand, B., M. Montfort, A. Chabás, L. Vilageliu, D. Grinberg, and A. Chabas. 1997. Hum. Genet. 100: 75-79.

Demina, A, E. Boas, and E. Beutler. 1997. Hematopathol. Mol. Hematol. (in press).

Erikson, A. 1986. Acta Paediatr. Scand. 326: 742.

Glenn, D., T. Gelbart, and E. Beutler. 1994. Hum. Genet. 93: 635-638.

Horowitz, M., G. Tzuri, N. Eyal, A. Berebi, E.H. Kolodny, R.O. Brady, N.W. Barton, A. Abrahamov, and A. Zimran. 1993. Am. J. Hum. Genet. 53: 921-930.

Hrebicek, M., J. Zeman, J. Musilova, K. Hodanova, G.H. Renkema, L. Veprekova, J. Ledvinova, D. Hrebicek, J. Sokolova, J.M.F.G. Aerts, and M. Elleder. 1996. Virchows Arch. Int. J. Pathol. 429: 305-309.

Ida, H., O.M. Rennert, H. Kawame, K. Maekawa, and Y. Eto. 1997. J. Inherited M etab. Dis. 20: 67-73.

Le Coutre, P., A. Demina, E. Beutler, M. Beck, and P.E. Petrides. 1997. Hum. Genet. 99: 816821.

Meivar-Levy, I., M. Horowitz, and A.H. Futerman. 1994. Biochem. J. 303: 377-382.

Michelakakis, H., E. Dimitriou, S. van Weely, R.G. Boot, I. Mavridou, M. Verhoek, and J.M.F.G. Aerts. 1995. J. Inherital. Metab. Dis. 18: $609-615$.

Mistry, P.K. 1995. Lancet 346: 982.

Pasmanik-Chor, M., L. Madar-Shapiro, O.E. Stein, H. Aerts, S. Gatt, and M. Horowitz. 1997. Hum. Mol. Genet. 6: 887-895.

Uyama, E., K. Takahashi, M. Owada, R. Oka- mura, M. Naito, S. Tsuji, S. Kawasaki, and S. Araki. 1992. Acta. Neurol. Scand. 86: 407-420.

Uyama, E., M. Uchino, H. Ida, Y. Eto, and M. Owada 1997. J. Med. Genet. 34: 175.

van Weely, S., M. Van den Berg, J.A. Barranger, M.C. Sa Miranda, J.M. Tager, and J.M.F.G. Aerts. 1993. J. Clin. Invest. 91: 11671175.

Winfield, S.L., N. Tayebi, B.M. Martin, E.I. Ginns, and E. Sidransky. 1997. Genome Res. (this issue). 


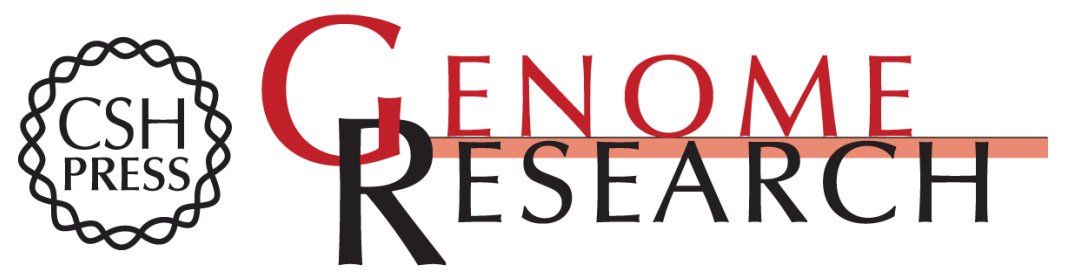

\section{Gaucher Disease Phenotypes Outflanked?}

Ernest Beutler

Genome Res. 1997 7: 950-951

Access the most recent version at doi:10.1101/gr.7.10.950

References This article cites 16 articles, 3 of which can be accessed free at:

http://genome.cshlp.org/content/7/10/950.full.html\#ref-list-1

\section{License}

Email Alerting Receive free email alerts when new articles cite this article - sign up in the box at the Service top right corner of the article or click here.

\section{Affordable, Accurate Sequencing.}

To subscribe to Genome Research go to: https://genome.cshlp.org/subscriptions 